Article

\title{
Thin-Walled CFST Columns for Enhancing Seismic Collapse Performance of High-Rise Steel Frames
}

\author{
Yongtao Bai ${ }^{1}$, Jiantao Wang ${ }^{1}$, Yashuang Liu ${ }^{2}$ and Xuchuan Lin ${ }^{3, *}$ \\ 1 Department of Civil Engineering, Xi'an Jiaotong University, Xi'an 710049, China; \\ baiyongtao@xjtu.edu.cn (Y.B.); wangjiantao@stu.xjtu.edu.cn (J.W.) \\ 2 School of Architectural Engineering, Beijing University of Technology, Beijing 100124, China; \\ lys635@163.com \\ 3 Institute of Engineering Mechanics, China Earthquake Administration, Harbin 150080, China \\ * Correspondence: linxuchuan@iem.ac.cn; Tel.: +86-182-0123-7617
}

Academic Editor: Zhong Tao

Received: 30 November 2016; Accepted: 24 December 2016; Published: 5 January 2017

\begin{abstract}
This paper numerically studied the collapse capacity of high-rise steel moment-resisting frames (SMRFs) using various width-to-thickness members subjected to successive earthquakes. It was found that the long-period component of earthquakes obviously correlates with the first-mode period of high-rises controlled by the total number of stories. A higher building tends to produce more significant component deterioration to enlarge the maximum story drift angle at lower stories. The width-to-thickness ratio of beam and column components overtly affects the collapse capacity when the plastic deformation extensively develops. The ratio of residual to maximum story drift angle is significantly sensitive to the collapse capacity of various building models. A thin-walled concrete filled steel tubular (CFST) column is proposed as one efficient alternative to enhance the overall stiffness and deformation capacity of the high-rise SMRFs with fragile collapse performance. With the equivalent flexural stiffness, CFST-MRF buildings with thin-walled members demonstrate higher capacity to avoid collapse, and the greater collapse margin indicates that CFST-MRFs are a reasonable system for high-rises in seismic prone regions.
\end{abstract}

Keywords: thin-walled structures; concrete filled steel tubes; high-rise buildings; seismic performance; dynamic collapse; local buckling

\section{Introduction}

The 2011 Great East Japan earthquake had devastating losses on human life, buildings and infrastructures near the seismic epicenter, and long-period ground motions excited resonance with high-rise buildings [1]. Extensive high-rise steel buildings were constructed during the period 1965 2000, especially in the period of construction-boom (i.e., 1980 1995) of high-rise buildings. CFST (concrete filled steel tubular) columns have been more adopted in high-rise buildings since 1992. There is a high probability that severe earthquakes with magnitude class over the design expectation might occur in the coming years [2]. Severe damage and collapse potentials exist in existing high-rise buildings.

Several studies on the collapse behavior of steel frame were addressed. Symmetry limit theory for steel beam-columns originally revealed the steady-state path of cantilever members [3,4]. A symmetry limit theory has been extended to reveal the phenomenon of deformation concentration at lower stories in the process of dynamic instability for the weak-beam-type frames [5]. Seismic resistance capacity of high-rise buildings subjected to long-period ground motions was studied on the basis of E-Defense shaking table tests [6]. Sidesway collapse of deteriorating structural systems under seismic excitations was analytically and experimentally addressed [7]. However, the strength deterioration such as local 
buckling has not been fully investigated in the evaluation of seismic-resistant capacity of high-rise steel buildings with thin-walled sectional members.

The behavior of CFST columns and structural systems has been investigated. Tao et al. experimentally investigated the behavior of CFST stub columns, and beam columns under various loading protocols have also been investigated [8-15]. They found that CFST demonstrated ductile behavior for the applications in seismic resistant structures. A fiber element model that is able to predict the ultimate response of CFST members was also presented and agreed well with the experimental results. Kawano and Sakino (2003) investigated the seismic resistance of CFST trusses [16,17]. Kawakami et al. (2004) studied a method to improve the distribution of story drift angle responses in CFST moment-resistant frames under severe earthquakes [18]. Nakahara et al. (2008) conducted a research on the bond behavior of concrete filled steel tubular frames under cyclic horizontal load [19]. Han et al. (2009) experimentally studied the seismic behavior of concrete-filled steel tubular frame to reinforced concrete (RC) shear wall high-rise mixed structures [20]. Nenavit and Hajjar (2012) conducted a nonlinear seismic analysis of circular concrete-filled steel tube members and frames [21]. Nevertheless, the research on deterioration behavior and collapse-resistant capacity of high-rise CFST buildings, especially considering the effect of member deterioration, is still limited. Since the existing high-rise steel moment-resisting frames (SMRFs) entail collapse potential when subjected to long-period ground motions, CFST columns are proposed to substitute the hollow steel section (HSS) columns because the composite action can delay the local buckling and improve the strength of in-filled concrete.

In this paper, the seismic performance of existing high-rise SMRFs with compact and thin-walled members subjected to over-design long-period ground motions is numerically studied. The effect of component deterioration is taken into account to investigate the collapse capacity. Then, thin-walled CFST columns are used to replace the HSS columns in high-rise SMRFs based on flexural stiffness, in order to enhance the collapse margin of the high-rise SMRFs that demonstrated fragile collapse capacity.

\section{Modeling and Analysis Methods}

\subsection{Simplified Fiber Element Models}

A fiber element program that has been developed is utilized to conduct the elasto-plastic analysis of structures under various loading procedures $[16,22]$. The stiffness of cross sections is numerically integrated by dividing the section into a number of parallel layers referred to as stress fibers. Accurate nonlinear stress-strain models are applied to these fibers to define the mechanical behavior of each member. The law of fiber discretization for $\mathrm{H}$-shaped steel and hollow section members is shown in Figure 1.

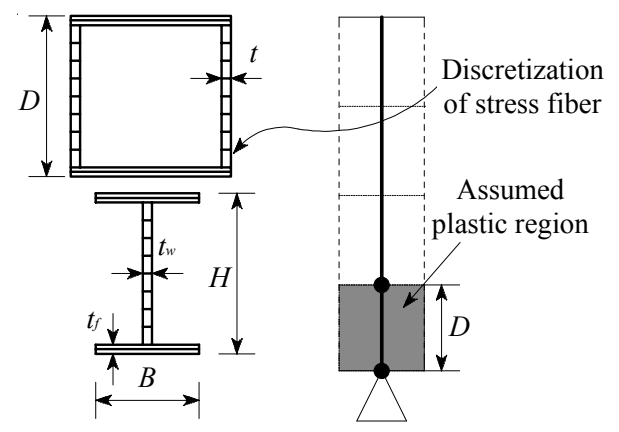

Figure 1. Fiber element discretization and plastic region.

On the longitudinal definition of elements, the plastic length at both ends of each element depends on the thickness and outer size of the steel tubes. In this study, the plastic length is determined as a constant value, but the stress-strain models are consistent with the assumption of the constant 
plastic length of the member depth $\mathrm{D}$, as shown in Figure 1. In the frame analysis program, the geometric nonlinearity has been rigorously formulated by adopting the moving coordinate system for each element. Therefore, the program can trace the nonlinear behavior up to collapse phenomenon. For dynamic analysis, the time history response of high-rise building models is calculated by the average acceleration method $(\beta=1 / 4)$, based on the Newmark's method. The convergence is guaranteed based on Newton-Raphson method.

The patterns of local buckling of HSS and CFST members are obviously different due to the confined effect by in-filled concrete. For unfilled rectangular or square CFSTs under axial compression, the inward buckling is effectively prevented. Thus, the local buckling pattern of steel tubes influences strength deterioration with internal restraint from the in-filled concrete.

Figure 2 shows the stress-strain relation for steel material with and without deterioration effects. The post-buckling strength deterioration and the corresponding negative slope in compressive direction enlarges the ratio of residual to maximum strain. The stress-strain models for confined concrete in CFST columns are shown in Figure 3. The post-crushing strength degradation reduces the unloading stiffness if the ratio of residual to maximum strain is a constant value [23]. Note that the splitting crack of the confined concrete in CFST columns occurs when the associated tubular face is subjected to tensile force. In this loading condition, the CFST columns enable the support of plastic deformation without the local buckling in steel tubes. In addition, the tensile strength of the confined concrete is much less than the yielding strength of steel tubes. Thus, the splitting crack can be neglected in the stress-strain relation of the concrete model [24].

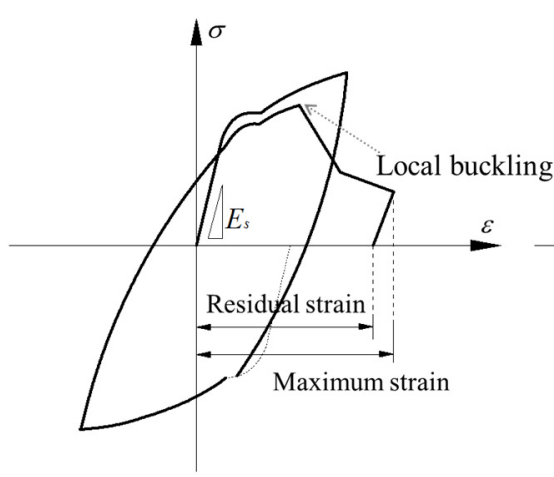

(a)

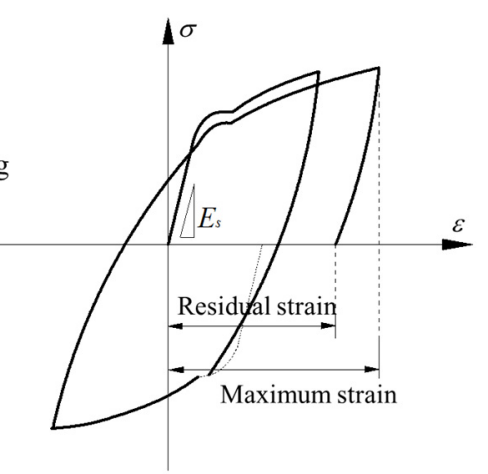

(b)

Figure 2. Stress-strain relation of thin-walled steel sections. (a) Model with post-buckling deterioration; (b) Model without post-buckling deterioration.

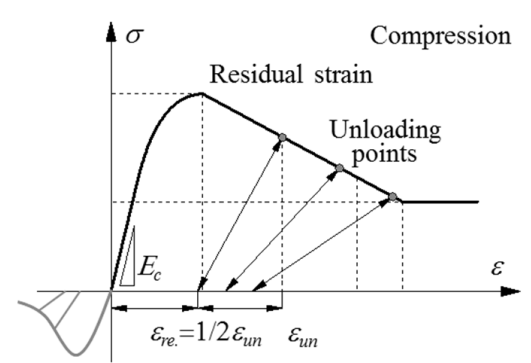

(a)

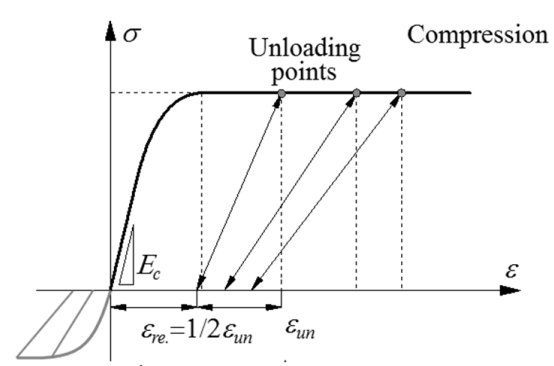

(b)

Figure 3. Stress-strain relation of confined concrete. (a) Model with post-crushing deterioration; (b) Model without post-crushing deterioration.

In the numerical simulations of steel and CFST structures using the fiber element method, it is assumed that the cross section remains plane, and the strain distribution keeps linear along with the 
depth of the cross section. The stress should be located at the centroid of each parallel fiber element, and vertical discretization is neglected for torsion or bi-axial bending. Besides, the effects of creep and shrinkage of concrete were not in the scope of this paper. The confinement effect and slipping of concrete on the strength and deterioration are taken into account in the normalized stress-strain relationship of the confined concrete. Post local-buckling strength and stiffness deterioration of steel tubular walls is taken into account in the constitutive relationship of steel plate elements.

\subsection{Thin-Walled Steel Columns}

The width-to-thickness ratio, $\lambda$, has been classified to control the occurrence of local buckling of flexural $\mathrm{H}$-shaped steel members [25]. The $\lambda$ of $\mathrm{H}$-shaped steel beams is classified as a compact cross section (FA represents a compact cross section) when $\lambda$ is equal to or less than $9 \sqrt{235 / F y}$, and the non-compact cross section (FB represents a non-compact cross section) when $\lambda$ is equal to or less than $11 \sqrt{235 / F y}$ for flanges, where $F_{y}$ is the nominal yield strength of steel materials. For square hollow steel sectional columns, the critical values of the compact and non-compact cross sections are given as $33 \sqrt{235 / F y}$ and 37 $\sqrt{235 / F y}$. Note that the above $\lambda$ are classified on the basis of the various types of steel materials. Both of the above advantages contribute to the ductile behavior of the CFST column due to the delay of local-buckling and the confined effect on the in-filled concrete. The compact and thin-walled CFST columns are employed in high-rise CFST building models in order to be analogous to the steel moment-resisting frame (SMRF) building models with various sectional compactness.

According to the Recommendations for the Design and Construction of Concrete Filled Steel Tubular Structures [26] — different from the ranks of the width-thickness ratio (FA, FB) on HSS members by the Building Standards Act of Japan [25] — the ranks of the width-thickness ratio $(B / t)$ of CFST members is required differently, such as $R_{u} \geq 0.02$ for the compact FA section; and $R_{u} \geq 0.02$ for the thin-walled FB section. Rectangular CFST members can be $R_{u}$ calculated as

$$
R_{u}=\frac{\gamma_{r}}{0.15+3.79 \frac{N}{N_{0}}} \cdot \frac{t}{B} \cdot{ }_{R} \alpha
$$

where $B$ is the width of the rectangular steel tube, $t$ is the thickness of the steel tube, $F_{c}$ is the nominal design strength of the concrete, $N$ is axial loading, $N_{0}$ is the yield strength of the CFST columns which is approximately equal to $A_{s} \cdot f_{y}+A_{c} \cdot f_{c}, \gamma_{r}$ is a coefficient defined by the buckling length $l_{k}$ of the CFST members, (if $l_{k} / D \leq 10, \gamma_{r}=1.0$, if $\left.l_{k} / D>10, \gamma_{r}=0.8\right)$, and ${ }_{R} \alpha$ is defined as follows:

$$
{ }_{R} \alpha=1.0-\frac{F_{c}-40.3}{566}, \text { if }_{R} \alpha \geq 1,{ }_{R} \alpha=1
$$

\section{Seismic Performance of the Thin-Walled SMRFs}

\subsection{Building Models}

Extensive high-rise steel buildings have been constructed since 1965, especially during the construction-boom period of high-rises in the 1980s. CFST columns were initially employed in high-rise steel buildings in Japan [2]. Figure 4 shows a tendency of the various structural systems for high-rises based on 300 building cases higher than 100 meters constructed from 1966 to 1998 in Japan. The CFST system shows a stably ascending tendency since 1981. In addition, the HSS columns in the high-rise buildings higher than 80 meters usually filled with concrete but this was not accounted as CFST buildings. Thus, the realistic number of existing high-rise CFST buildings should be higher than what is presented in the statistical database as provided in Figure 4.

Generic existing high-rise steel moment-resisting frames with 20, 30 and 40 story levels are selected as the prototypes, as shown in Figure 5. The damping factor of the building models is simply assumed as an identical value of $2 \%$ in order to eliminate the influence of the varying damping factors on the seismic responses of structures. The slab composite action for beam components, the P- $\Delta$ effect 
and strong-column weak-beam are considered in the structural design. The high-rise building models are seismically designed according to current Japanese seismic design standards [27]. The design base shear coefficient is obtained based on the standard shear coefficient of the seismic demand of buildings, the seismic intensity of areas, and the types of ground soils. According to the statistical database on high-rises of steel and CFST buildings, steel materials of SM490 and SN490 are the most frequently used in existing steel office buildings, therefore the steel material SM490 and SN490 with the nominal yield strength of $\sigma_{y}=320 \mathrm{MPa}$ and the ultimate tensile strength of $\sigma_{u}=490 \mathrm{MPa}$ are used in the modelling of high-rise building models in this paper. Besides, the concrete with the compressive strength of $60 \mathrm{MPa}$ is used in the composite slabs and CFST columns. Design procedures include, the allowable stress method and time-history dynamic analyses subjected to moderate rare earthquakes controlled by peak ground velocity (PGV). The input ground motions for the dynamic design include Art-Hachi as a synthetic wave, El-Centro-NS, Hachinohe-NS and Tafe-EW as observed waves. Besides, CHB009-NS and C-San-EW waves are long-period ground motions with the intensity of a maximum capacity earthquake (Level 2).

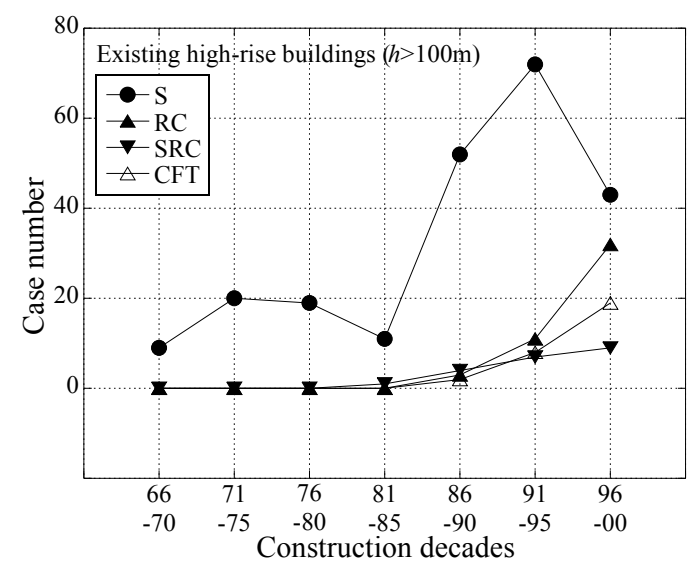

Figure 4. Statistical databases of various existent high-rise buildings.
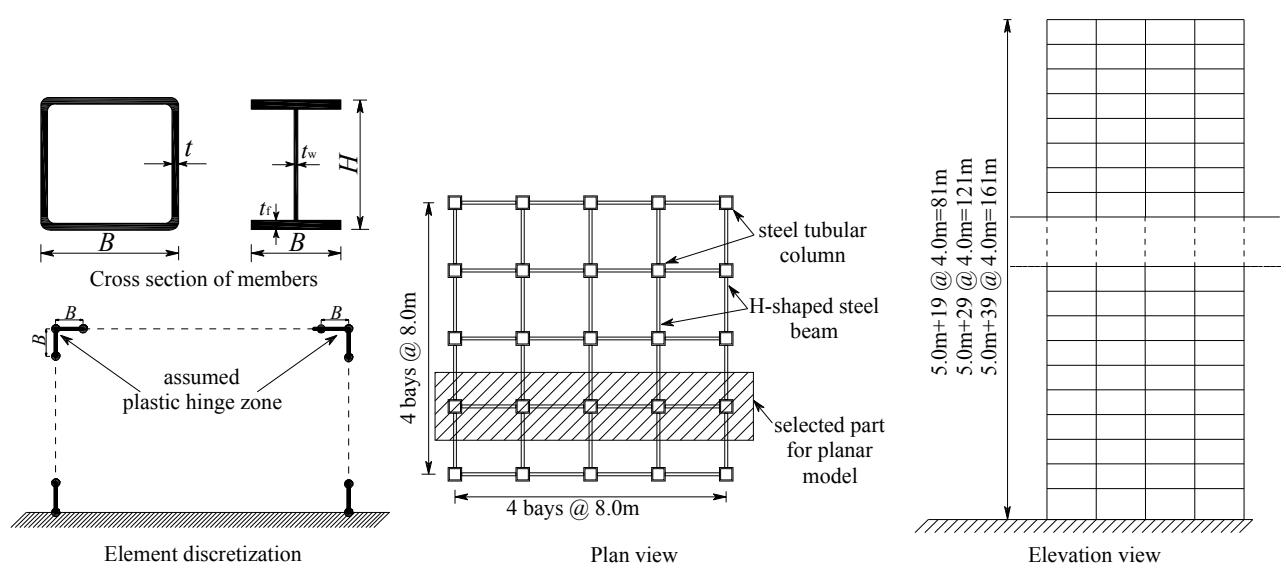

Figure 5. Members, element discretization, plan and elevation view of high-rise SMRF (steel moment-resisting frame) models.

\subsection{Model Validation}

The numerical model is validated by simulating a static cyclic test on a planar CFST frame with three stories under cyclic loading $[23,28]$. The frame specimen was constructed by square CFST columns and H-shaped steel beams. The cross section of the CFST columns is uniformly fabricated as $150 \times 150 \times 4.5$ using the steel material STKR400 with $\sigma_{y}=409 \mathrm{MPa}$ and $\sigma_{u}=477 \mathrm{MPa}$. 
The BH-200 $\times 100 \times 6 \times 6 \mathrm{H}$-shaped steel using the steel material SS400 with $\sigma_{y}=337 \mathrm{~N} / \mathrm{mm}^{2}$ and $\sigma_{u}=444 \mathrm{~N} / \mathrm{mm}^{2}$, is adopted as the beam components. The compressive strength of the infilled concrete in CFST columns is $31.3 \mathrm{MPa}$ based on four concrete cylinder test results. Horizontal cyclic loading is applied on the top of the frame specimen, and constant axial loads with the axial load ratio $N=0.2 \cdot{ }_{c} N_{u} \times 2$ are applied on two CFST columns simultaneously. Figure 6 shows the elevation view of the CFST frame model.

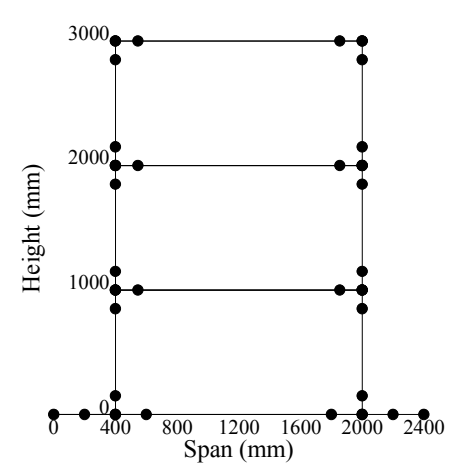

Figure 6. Modelling of the CFST (concrete filled steel tubular) frame specimen.

Comparisons of hysteretic load $(\mathrm{H})$ versus roof drift ratio $(\mathrm{R})$ curve between experimental and analytical results are presented in Figure 7 . The hysteretic curve before $\mathrm{R} \leq 2 \%$ shows slight plastic deformation while the strength degradation was not induced by local buckling. Furthermore, local buckling was triggered, associated with post-peak strength deterioration which was incorporated in the numerical modeling. More than $85 \%$ of the maximum strength is maintained; even the roof drift ratio $\mathrm{R}$ reaches $5 \%$. Through simulating this cyclic test of the CFST frame, the numerical modeling approach is promising to accurately predict the seismic behavior of CFST frames, including the elasto-plasticity, damages and strength deterioration. The seismic performance of CFST frame structures would be overestimated if the deterioration effects of steel tube and confined concrete were neglected. Hence, deterioration effects should be appropriately considered in simulating the seismic performance of high-rise steel and CFST buildings.

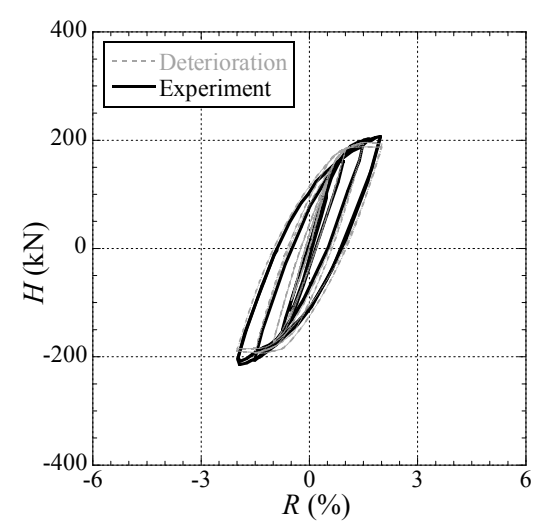

(a)

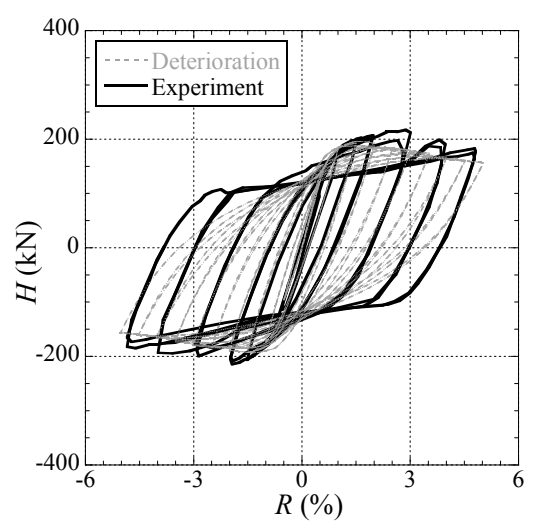

(b)

Figure 7. Comparisons between simulation results and experimental results. (a) Hysteretic curve when $\mathrm{R} \leq 2 \%$; (b) Hysteretic curve when $\mathrm{R}=5$.

\subsection{Dynamic Analysis}

Time-history dynamic analysis on high-rise SMRFs under the Level 2 earthquakes is conducted to compare the seismic responses of the building using compact and thin-walled members. The ground 
motions C-San-EW is a long-period ground motion synthesized based on the characteristics of basin areas near the Pacific Ocean, and CHB009-NS was observed in the Great East Japan earthquake, 2011. Maximum story drift angle $\theta_{\max , i}$ of the $i$ th-story can be calculated by the horizontal drift of the $i$ th-story divided by the story height. Figures 8 and 9 show the distributions of the $\theta_{\max , i}$ for the SMRFs with various overall story levels.

The seismic demand of Level $2\left(\theta_{\max } \leq 0.01\right)$ was satisfied when subjected to Art-Hachi, El-Centro-NS, Hachinohe-NS and Tafe-EW waves, while the C-San-EW wave excited excessive story drifts on the $20 \mathrm{~S}$ and $30 \mathrm{~S}$ models. This means that the high-rise SMRFs fulfill the same seismic demand at design level regardless of the width-to-thickness ratios of members. The long-period component of earthquake waves obviously correlates with the first-mode period of high-rises which is controlled by the total number of stories. For instance, the C-San-EW wave shows extremely large excitation on the structures with 'first-mode' natural period $T_{1}$ between $2 \mathrm{~s}$ and $4 \mathrm{~s}$. In contrast, the maximum story drift angle subjected to the observed CHB009-NS is relatively small; even the wave is characterized with the long-period component.

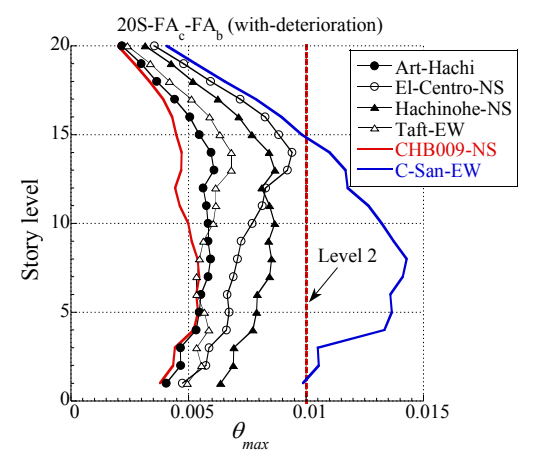

(a)

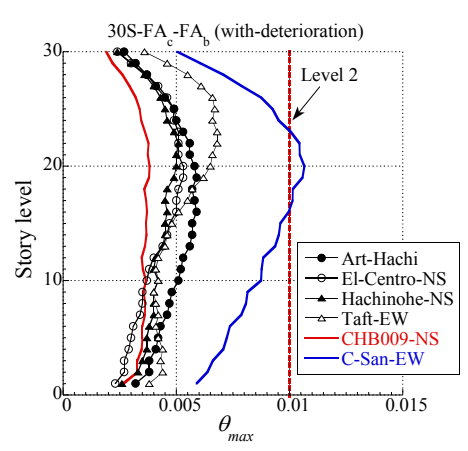

(b)

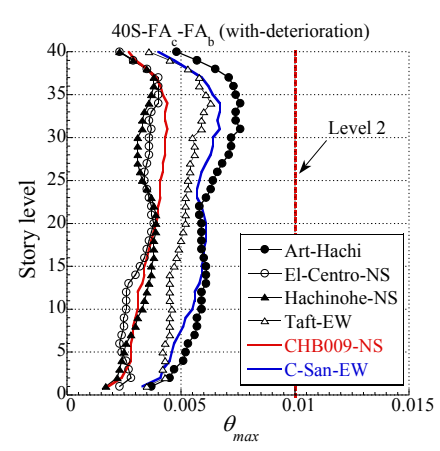

(c)

Figure 8. Maximum story drift angle of high-rise SMRFs with compact members under Level 2 earthquakes. (a) $20 \mathrm{~S}$ model; (b) $30 \mathrm{~S}$ model; (c) $40 \mathrm{~S}$ model.

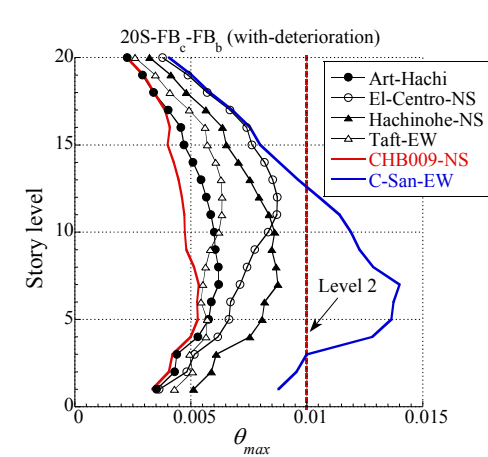

(a)

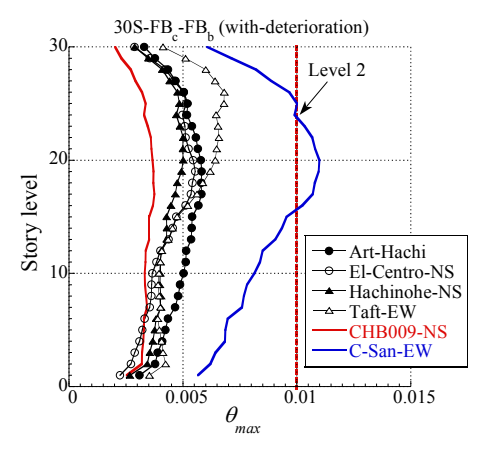

(b)

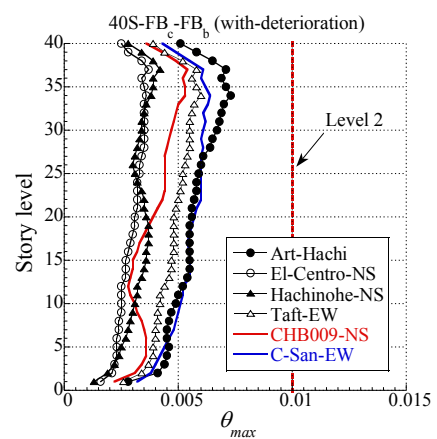

(c)

Figure 9. Maximum story drift angle of high-rise SMRFs with thin-walled members under Level 2 earthquakes. (a) $20 \mathrm{~S}$ model; (b) $30 \mathrm{~S}$ model; (c) $40 \mathrm{~S}$ model.

The collapse capacity of high-rise SMRFs with thin-walled FB members (20S-FB $-\mathrm{FB}_{\mathrm{b}}$, where the subscripts $c$ and $b$ indicate column and beam components) is assessed based on the incremental dynamic analysis (IDA) method by excessively scaling the intensity of input ground motions. The IDA approach was proposed on the basis of the analogy with the incremental static push-over (SPO) analysis. IDA was developed by [29], and is widely used in collapse studies [30,31]. The IDA method is capable of estimating the seismic performance of building structures covering the whole process 
from elastic to ultimate global collapse eventually. Usually, the IDA approach requires a sufficient amount of input ground motions to run time-history analysis to eliminate the uncertainty from the variety of ground motions. In this study, since the high-rise building systems highly relate to the characteristics of long-period ground motions, the Art-Hachi with flat velocity spectral shape is used to provide stable excitations in the wide range of the long-period domain.

Figure 10 shows the vertical distribution of the maximum story drift angle of thin-walled FB buildings with 20,30 and 40 story levels. $\phi$ is the incremental factor of the Art-Hachi wave. Note that higher buildings produce more significant component deterioration to enlarge the maximum story drift angle. The deterioration effects triggered by the local buckling amplify the $\theta_{\max }$ at lower stories and reduce the $\theta_{\max }$ at higher stories because the inflexion point changes the deflection pattern. For instance, the inflexion point is located at the fifth floor for the $20 \mathrm{~S}-\mathrm{FB}_{\mathrm{c}}-\mathrm{FB}_{\mathrm{b}}$ building when the $\phi$ is scaled to 3. Thus, the width-to-thickness ratio (FB rank) of beam and column components overtly has effects on the seismic responses when the plastic deformation extensively develops. In particular, the collapse capacity of the $40 \mathrm{~S}-\mathrm{FB}_{\mathrm{c}}-\mathrm{FB}_{\mathrm{b}}$ model is captured at the Art-Hachi $(\phi=2,3)$.

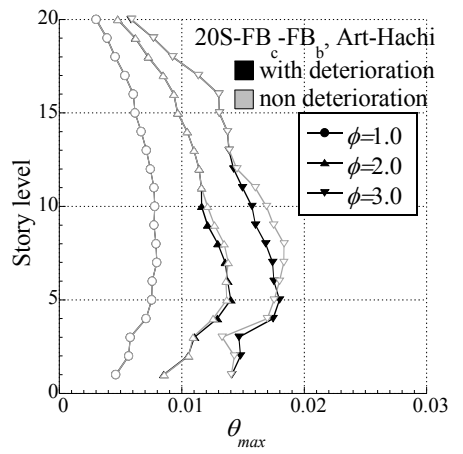

(a)

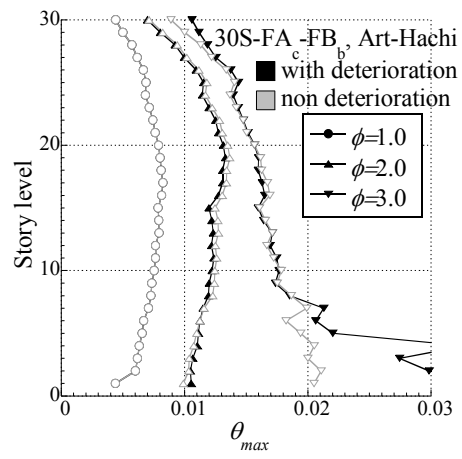

(b)

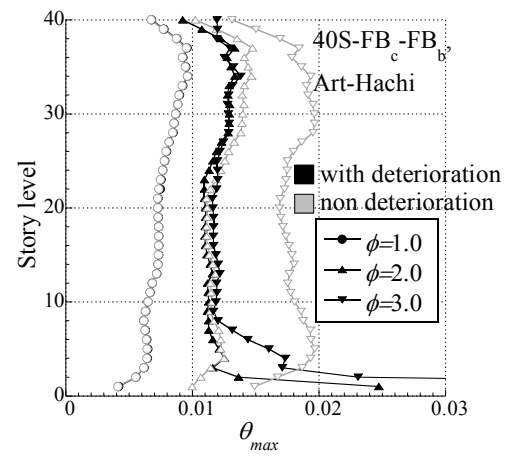

(c)

Figure 10. Distribution of maximum story drift angle of high-rise SMRF models with thin-walled members. (a) 20S- $\mathrm{FB}_{\mathrm{c}}-\mathrm{FB}_{\mathrm{b}}$; (b) $30 \mathrm{~S}-\mathrm{FB}_{\mathrm{c}}-\mathrm{FB}_{\mathrm{b}}$; (c) $40 \mathrm{~S}-\mathrm{FB}_{\mathrm{c}}-\mathrm{FB}_{\mathrm{b}}$.

Ultimate sidesway collapse is regarded when the induced story drift angle does not recover, meaning the residual story drift angle is equal to the maximum story drift angle. The relation between the maximum and residual story drift angle with respect to the incremental factor is plotted to present the incipient collapse, as shown in Figure 11. Residual story drift angle stays at a low deformation level (i.e., $0.01 \mathrm{rad}$ ), and becomes very sensitive to the intensity of ground motions. The collapse potential of the $40 \mathrm{~S}-\mathrm{FB}_{\mathrm{c}}-\mathrm{FB}_{\mathrm{b}}$ building exists when the incremental factor of Art-Hachi is scaled to 2 . The ratio of residual to maximum story drift angle is an important indicator to judge the criteria of incipient collapse.

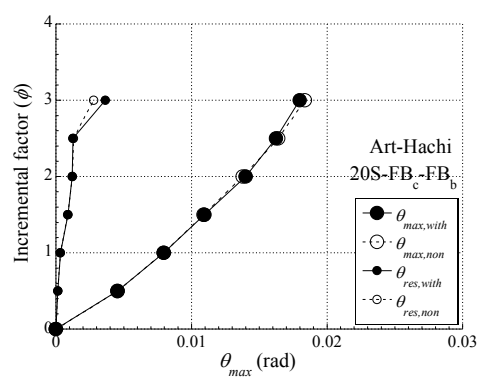

(a)

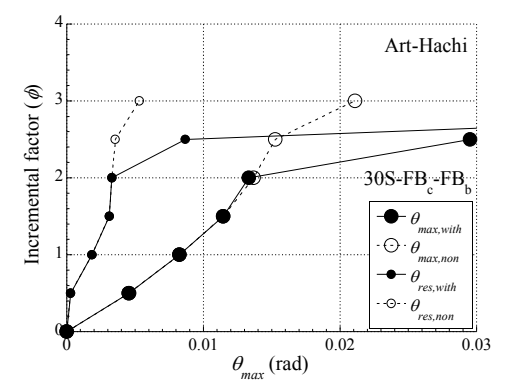

(b)

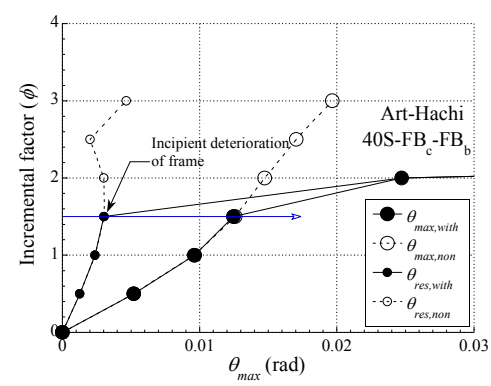

(c)

Figure 11. Incremental maximum and residual story drift angles of $20 \mathrm{~S}$ building models. (a) $20 \mathrm{~S}-\mathrm{FB}_{\mathrm{c}}-\mathrm{FB}_{\mathrm{b}}$; (b) $30 \mathrm{~S}-\mathrm{FB}_{\mathrm{c}}-\mathrm{FB}_{\mathrm{b}}$; (c) $40 \mathrm{~S}-\mathrm{FB}_{\mathrm{c}}-\mathrm{FB}_{\mathrm{b}}$. 


\section{Collapse Mitigation Using CFST Columns}

\subsection{CFST Columns with Equivalent Capacity}

As discussed in the previous section, the collapse potential of high-rise SMRFs with thin-walled sectional columns exists when subjected to strong earthquakes that exceed the design criterion. Effective alternatives for enhancing the collapse capacity should be proposed based on either equivalent flexural stiffness $K\left(12 E I / h^{3}\right)$ or ultimate strength $M_{u}$. In seismic design, the flexural stiffness dominates the deformation capacity to resist moderate earthquakes. The CFST columns with equivalent flexural stiffness efficiently reduce the size of cross sections or the thickness in terms of the same cross section, as shown in Figure 12. Besides, the composite effects delay the local buckling of restrained tubes and improve the crushing strength of confined concrete. Given this consideration, equivalent CFST members substitute the thin-walled HSS columns to build the comparative high-rise CFST-MRFs, as summarized in Table 1. The same analysis procedures performed in the previous section were repeated to quantify the enhancement of collapse capacity by using the thin-walled CFST columns.

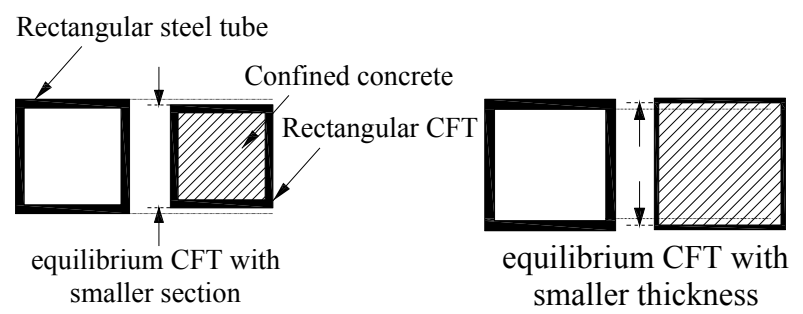

Figure 12. CFST columns equivalent to the HSS (hollow steel section) columns.

Table 1. Details of various high-rise building models.

\begin{tabular}{cccccc}
\hline Case & $\begin{array}{c}\text { Component } \\
\text { (Column, Beam) }\end{array}$ & $\begin{array}{c}\text { Height } \\
\text { (Story) }\end{array}$ & $\begin{array}{c}\text { Width-to-Thickness } \\
\text { Ranks (Column, Beam) }\end{array}$ & $\begin{array}{c}\text { 'First Mode' } \\
\text { Natural Period }\end{array}$ & B/t Ratio \\
\hline \multirow{2}{*}{ SMRF $^{1}$} & HSS $^{1}$ columns, & $81 \mathrm{~m}(20)$ & FA, FA & $2.32 \sim 2.38 \mathrm{~s}$ & \\
& H-shaped beams & $121 \mathrm{~m}(30)$ & FA, FB & $3.54 \sim 3.61 \mathrm{~s}$ & $17 \sim 30$ \\
& $161 \mathrm{~m}(40)$ & FB, FB & $4.53 \sim 4.66 \mathrm{~s}$ & \\
\hline \multirow{2}{*}{ CFST-MRF $^{1}$} & CFST columns, & $81 \mathrm{~m}(20)$ & FA, FA & $2.26 \sim 2.32 \mathrm{~s}$ & \\
& H-shaped beams & $121 \mathrm{~m} \mathrm{(30)}$ & FA, FB & $3.32 \sim 3.47 \mathrm{~s}$ & $14 \sim 40$ \\
\hline
\end{tabular}

${ }^{1}$ SMRF: steel moment-resisting frames; HSS: hollow steel section; CFST: concrete filled steel tubular; MRF: moment-resisting frames.

\subsection{Collapse Capacity Enhancement}

As discussed in the previous section, the $40 \mathrm{~S}-\mathrm{FB}_{\mathrm{c}}-\mathrm{FB}_{\mathrm{b}}$ building showed the most significant sensitivity to global collapse in the range of the intensity of ground motion (e.g., Art-Hachi: $P G V=210 \mathrm{~m} / \mathrm{s}, \phi=2)$. The thin-walled CFST columns with equivalent flexural stiffness are used to substitute the HSS columns in the $40 \mathrm{~S}-\mathrm{FB}_{\mathrm{c}}-\mathrm{FB}_{\mathrm{b}}$ building, aiming to improve the intensity of ground motions associated with the incipient collapse. Figure 13 shows the distribution of maximum story drift angle of the $40 \mathrm{~S}-\mathrm{FB}_{\mathrm{c}}-\mathrm{FB}_{\mathrm{b}}$ and the comparative $40 \mathrm{CFT}$-high-det. $\left(\mathrm{FB}_{\mathrm{c}}-\mathrm{FB}_{\mathrm{b}}\right)$ buildings when subjected to the Art-Hachi with $\phi=2$. It is noted that sidesway collapse at the bottom two stories of the $40 S-\mathrm{FB}_{\mathrm{c}}-\mathrm{FB}_{\mathrm{b}}$ building is efficiently prevented by using a thin-walled CFST column. This implies that high-deterioration significantly influences the collapse resistant capacity of high-rise SMRF buildings under high-level ground motions that have a larger probability of occurrence than the building model with a low level of deterioration effect. 


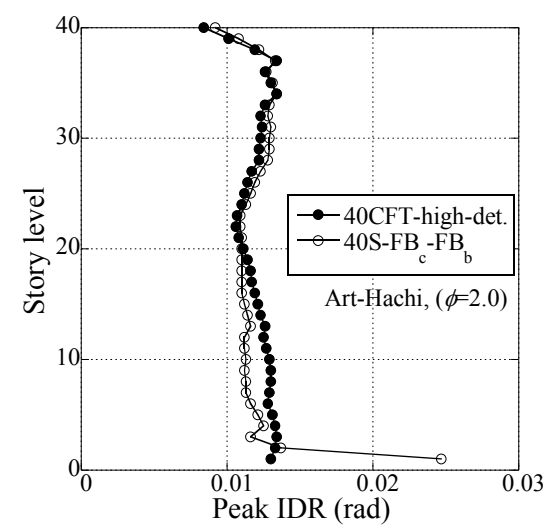

Figure 13. Distribution of maximum story drift angle of high-rise SMRF and CFST-MRF (moment resisting frame) models.

For the collapse safety of various high-rise buildings, the SMRFs with thin-walled members face larger challenges of collapse than the equivalent CFST-MRFs. From the demonstration in Figure 14, the incipient collapse has been induced with different intensity levels, indicating that the collapse capacity of the SMRFs with thin-walled members is enhanced by the CFST-MRF buildings with the equivalent flexural stiffness. The $40 \mathrm{~S}-\mathrm{FB}_{\mathrm{c}}-\mathrm{FB}_{\mathrm{b}}$ building could collapse until the $\phi$ is up to around 1.5, while the incipient collapse of the $40 \mathrm{CFT}-\mathrm{S}_{\mathrm{c}}-\mathrm{FB}_{\mathrm{b}}$ building model did not occur until the $\phi$ achieves around 4.0.

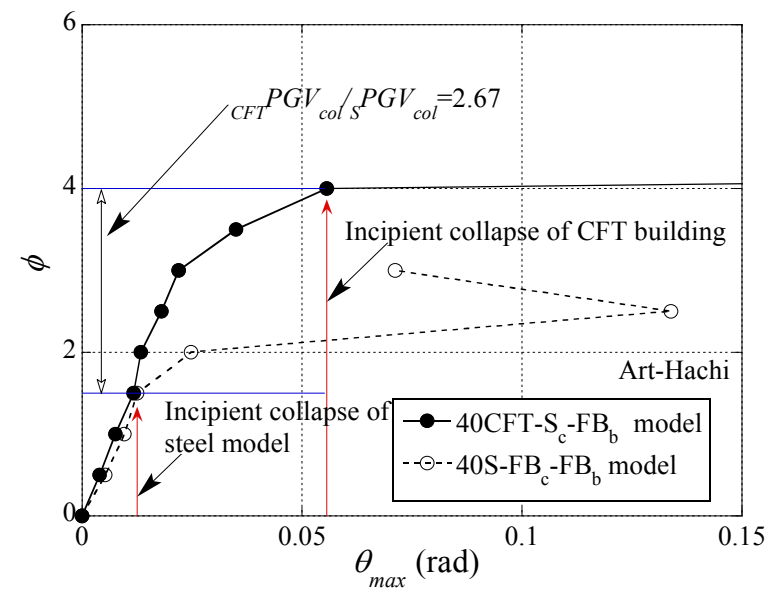

Figure 14. Incremental maximum story drift angle of high-rise SMRF and CFST-MRF models.

The high-rise CFST-MRFs demonstrate greater collapse capacity than the equivalent SMRFs, but this finding is only supported when the input ground motion is Art-Hachi. As mentioned before, the Art-Hachi wave is characterized by a flat velocity spectral shape in the domain of the long-period branch. Similar waves such as the BCJ-L2, Yokohama and JSCA-Kobe are selected to perform the IDA to compare the collapse capacity of these two types of high-rises.

Seismic response tends to become sensitive and collapse may occur suddenly after going beyond the limit-state of their collapse capacities. Thus, a collapse safety coefficient is proposed to quantify the seismic safety of buildings to prevent deterioration and collapse. A process that progresses from elasticity to elasto-plasticity until ultimate strength to component-deterioration and global-collapse. The PGV of earthquakes is considered to be associated with the corresponding performance demand in performance-based seismic design, e.g., the so called 'Level 2 ' is treated as the maximum capacity earthquake. The PGV at the Level 2 can be used as the reference to quantify the collapse margin. 
The relation between the intensity measure of the PGV and the performance indicator $\theta_{\max }$ of high-rise SMRF and CFST-MRF buildings under Art-Hachi, BCJ-L2, Yokohama and JSCA-Kobe waves are respectively demonstrated in Figure 15 . The average collapse margin $\lambda_{\text {col }}$ of the $40 \mathrm{CFT}-\mathrm{S}_{\mathrm{c}}-\mathrm{FB}_{\mathrm{b}}$ building is larger than 2.10 , which improves $60 \%$ compared to 1.34 of the $40 \mathrm{~S}-\mathrm{FB}_{\mathrm{c}}-\mathrm{FB}_{\mathrm{b}}$ building.
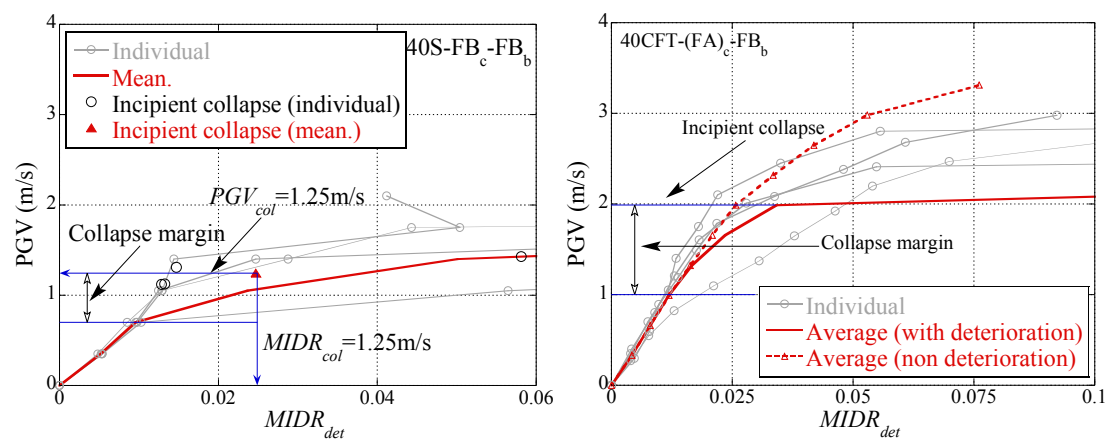

Figure 15. Average collapse margin of high-rise SMRF and CFST-MRF models.

\section{Conclusions}

In this paper, the collapse capacity of high-rise SMRFs using various width-to-thickness members subjected to successive earthquakes is numerically studied. It was found that the long-period component of earthquakes obviously correlates with the first-mode period of high-rises controlled by the total number of stories. Higher buildings tend to produce more significant component deterioration to enlarge the maximum story drift angle at lower stories. The width-to-thickness ratio (FB rank) of beam and column components overtly has effects on the collapse capacity when the plastic deformation extensively develops. The ratio of residual to maximum story drift angle is significantly sensitive to the collapse capacity of various building models. The thin-walled CFST column is proposed as one efficient alternative to enhance the overall stiffness and deformation capacity of the high-rise SMRFs with fragile collapse performance. With the equivalent flexural stiffness, thin-walled CFST columns are capable of improving the collapse margin for more than $60 \%$ of the high-rise SMRFs under the identical earthquakes. Based on the comparative study on the collapse capacity of high-rise SMRF and CFST-MRF buildings, CFST-MRF buildings demonstrate significantly higher capacity to avoid collapse, and the greater collapse margin indicates that CFST-MRFs are a reasonable system for high-rises in seismic prone regions. Moreover, constructional difficulties exist when the HSS columns are substituted by CFST columns in engineering practice, which needs further investigation.

Acknowledgments: The authors gratefully acknowledge the support for this research from the National Natural Science Foundation of China (NSFC) under Grant No. 51508459, Natural Science Foundation of Shaanxi Province (2016JQ5086), and China Postdoctoral Science Foundation Grant (2016M592792).

Author Contributions: Yongtao Bai contributed to the conception of this paper; Jiantao Wang and Yashuang Liu contributed to numerical modeling and dynamic analysis; Xuchuan Lin contributed to provide the earthquake database and discuss the results.

Conflicts of Interest: The authors declare no conflict of interest.

\section{References}

1. Architectural Institute of Japan. Preliminary Reconnaissance Report on the 2011 Off the Pacificcoast of Tohoku Earthquake; Architectural Institute of Japan: Tokyo, Japan, 2011.

2. Architectural Institute of Japan. Structural Response and Performance for Long Period Seismic Ground Motions; Architectural Institute of Japan: Tokyo, Japan, 2007.

3. Nakamura, T.; Uetani, K. Symmetry Limit Theory for Steel Beam-Columns (Part 1: A General Formulation). J. Struct. Constr. Eng. 1989, 398, 109-119. 
4. Nakamura, T.; Uetani, K. Symmetry Limit Theory for Steel Beam-Columns (Part 2: Finite Element Analysis. J. Struct. Constr. Eng. 1990, 408, 43-54.

5. Uetani, K.; Tagawa, H. Deformation Concentration Phenomena in the Process of Dynamic Collapse of Weak-Beam-Type Frames. J. Struct. Constr. Eng. 1996, 483, 51-60.

6. Chung, Y.; Nagae, T.; Hitaka, T.; Nakashima, M. Seismic Resistance, Capacity of High-Rise Buildings Subjected to Long-Period Ground Motions: E-Defense Shaking Table Test. J. Struct. Eng. 2010, 136, 637-644. [CrossRef]

7. Lignos, D.G.; Krawinkler, H.; Whittaker, A.S. Prediction and validation of sidesway collapse of two scale models of a 4-story steel moment frame. Earthq. Eng. Struct. Dyn. 2011, 40, 807-825. [CrossRef]

8. Tao, Z.; Han, L.H.; Zhao, X.L. Behaviour of concrete-filled double skin (CHS inner and CHS outer) steel tubular stub columns and beam-columns. J. Constr. Steel Res. 2004, 60, 1129-1158. [CrossRef]

9. Tao, Z.; Han, L.H.; Zhao, X.L. Experimental behaviour of stiffened concrete-filled thin-walled hollow steel structural (HSS) stub columns. J. Constr. Steel Res. 2005, 61, 962-983. [CrossRef]

10. Patel, V.I.; Uy, B.; Prajwal, K.A.; Aslani, F. Confined concrete model of circular, elliptical and octagonal CFST short columns. Steel Compos. Struct. Int. J. 2016, 22, 497-520. [CrossRef]

11. Patel, V.I.; Liang, Q.Q.; Hadi, M.N.S. Numerical analysis of high-strength concrete-filled steel tubular slender beam-columns under cyclic loading. J. Const. Steel Res. 2014, 92, 183-194. [CrossRef]

12. Montuori, R.; Piluso, V. Analysis and modelling of CFT members: Moment curvature analysis. Thin-Walled Struct. 2015, 86, 157-166. [CrossRef]

13. Elremaily, A.; Azizinamini, A. Behavior and strength of circular concrete-filled tube columns. J. Constr. Steel Res. 2002, 58, 1567-1591. [CrossRef]

14. Shams, M.; Saadeghvaziri, M.A. Nonlinear response of concrete-filled steel tubular columns under axial loading. ACI Struct. J. 1999, 96, 1009-1017.

15. Susantha, K.A.S.; Ge, H.; Usami, T. Cyclic analysis and capacity prediction of concrete-filled steel box columns. Earthq. Eng. Struct. Dyn. 2002, 31, 195-216. [CrossRef]

16. Kawano, A.; Sakino, K. Seismic Resistance of CFT trusses. Eng. Struct. 2003, 25, 607-619. [CrossRef]

17. Kawano, A.; Nejime, H.; Tokuda, M. Seismic-Resistant Capacity of Steel Multi-Story Frames with CFT Truss Beams. J. Struct. Constr. Eng. 2005, 589, 181-185.

18. Kawakami, S.; Kawano, A.; Okamoto, Y. A method to Improve Distribution of Story Drift Angle Responses in CFT Moment-Resistant Frames under Severe Earthquake. J. Struct. Constr. Eng. 2004, 585, 223-229.

19. Nakahara, H.; Sakino, K.; Kawano, A. Bond Behavior of Concrete Filled Steel Tubular Frames under Cyclic Horizontal Load. J. Struct. Constr. Eng. 2008, 73, 465-472. [CrossRef]

20. Han, L.; Li, W.; Yang, Y. Seismic behaviour of concrete-filled steel tubular frame to RC shear wall high-rise mixed structures. J. Constr. Steel Res. 2009, 65, 1249-1260. [CrossRef]

21. Denavit, M.D.; Hajjar, J.F. Nonlinear Seismic Analysis of Circular Concrete-Filled Steel Tube Members and Frames. J. Struct. Eng. 2012, 138, 1089-1098. [CrossRef]

22. Bai, Y.; Kawano, A.; Odawara, K.; Matsuo, S. Constitutive models for hollow steel tubes and concrete filled steel tubes considering the strength deterioration. J. Constr. Steel Res. 2012, 77, 1141-1150. [CrossRef]

23. Bai, Y.; Lin, X.; Mou, B. Numerical modeling on post-local buckling behavior of circular and square concrete filled steel tubular beam columns. Int. J. Steel Struct. 2016, 16, 1-16. [CrossRef]

24. Bai, Y.; Lin, X. Numerical simulation of collapse behavior of steel resistant frame considering post local buckling behavior. Thin Walled Struct. 2015, 94, 424-434.

25. Ministry of Land, Infrastructure, Transport and Tourism. Building Standards Act of Japan; MLIT: Tokyo, Japan, 2007.

26. Architectural Institute Japan. Recommendations for Design and Construction of Concrete Filled Steel Tubular Structures; Architectural Institute of Japan: Tokyo, Japan, 2008.

27. Bai, Y.; Shi, Y.; Deng, K. Collapse analysis of high-rise steel moment frames incorporating deterioration effects of column axial force-bending moment interaction. Eng. Struct. 2016, 127, 402-415. [CrossRef]

28. Sakai, J.; Matsui, C.; Yanagida, Y.; Hitaka, T.; Inumaru, K. A Study on Elastic-Plastic Behavior of 3-Story Frames with CFT Columns (Part 1); Summaries of Technical Papers of Annual Meeting Architectural Institute of Japan; C-1, Structures III, Timber Structures Steel Structures Steel Reinforced Concrete Structures; Architectural Institute of Japan: Tokyo, Japan, 2001; pp. 1163-1164. 
29. Vamvatsikos, D.; Cornell, C.A. Incremental Dynamic Analysis. Earthq. Eng. Struct. Dyn. 2002, 31, $491-514$. [CrossRef]

30. Zareian, F.; Krawinkler, H. Assessment of probability of collapse and designfor collapse safety. Earthq. Eng. Struct. Dyn. 2007, 36, 1901-1914. [CrossRef]

31. Liel, A.B.; Deierlein, G.G. Assessing the Collapse Risk of California's Existing Reinforced Concrete Frame Structures: Metrics for Seismic Safety Decisions; Report No. 166; The John A. Blume Earthquake Engineering Center, Stanford University: Stanford, CA, USA, 2008. 